九州大学学術情報リポジトリ

Kyushu University Institutional Repository

\title{
Degradation of a Non-Phenolic $\beta-0-4$ Lignin Model Dimer by Cerrena unicolor Laccase and Mediators, Acetovanillone and Acetosyringone
}

Cho, Nam-Seok

Wood and Paper Science, Chungbuk National University

Leonowicz, Andrzej

Department of Biochemistry, Maria Curie-sklodowska Univeristy

Jarosz-Wilkolazka, Anna

Department of Biochemistry, Maria Curie-sklodowska Univeristy

Ginalsika, Grazyna

Department of Biochemistry, Maria Curie-sklodowska Univeristy

他

https://doi.org/10.5109/10062

出版情報: 九州大学大学院農学研究院紀要. 53 (1)，pp.7-12，2008-02-28. Faculty of Agriculture， Kyushu University

バージョン :

権利関係 : 


\title{
Degradation of a Non-Phenolic $\beta-0-4$ Lignin Model Dimer by Cerrena unicolor Laccase and Mediators, Acetovanillone and Acetosyringone
}

\author{
Nam-Seok CHO ${ }^{1}$, Andrzej LEONOWICZ ${ }^{2}$, Anna JAROSZ-WILKOLAZKA ${ }^{2}$, \\ Grazyna GINALSKA ${ }^{2}$, Hee-Yeon $\mathrm{CHO}^{3}$, Soo-Jeong SHIN ${ }^{1}$, \\ Yun-Jeong CHOI ${ }^{1}$ and Shoji OHGA*
}

\author{
Laboratory of Forest Resources Management, Division of Forest Ecosphere Management, \\ Department of Forest and Forest Products Sciences, Kyushu University, \\ Sasaguri, Fukuoka 811-2415, Japan \\ (Received November 1, 2007 and accepted November 30, 2007)
}

\begin{abstract}
This study focuses on the laccase and mediator co-operation in modelling lignin dimer veratrylglycerol$\beta$-vanillate ether (VVE) oxidation. Earlier we stated that constitutive laccase isolated from Cerrena unicolor can cooperate with acetovanillone (AV) and acetosyringone (AS) in degradation of high molecular fraction of lignosulfonates. The fungus $C$. unicolor is known as a very good producer of cheap constitutive laccase. Its cultivation for this reason does not require stimulation by the expensive and toxic inducer like 2,5-xylidine. The main purpose of present study is to examine capability of $C$. unicolor laccase to oxidize VVE, which is a non-phenolic lignin model compound with external mediator HBT, and AV and AS in order to choose one, most efficient system. In the presence of laccase, generation of monomeric aromatic acids from non-phenolic lignin model dimer veratrylglycerol- $\beta$-vanillate ether (VVE) was observed. The addition of acetovanillone (AV) or acetosyringone (AS) intensified this process, i.e. transformation was more extensive than in the experiments omitting mediators. Among the products, isovanillic (IA) and vanillic (VA) acids were identified.
\end{abstract}

\section{INTRODUCTION}

Fungal laccases (benzenediol:oxygen oxireductases, EC 1.10.3.2) are a multicoper inducible oxidases reducing oxygen to water and simultaneously performing oneelectron oxidation of aromatic hydrogen donors (Leonowicz et al., 2001; Mayer and Staples, 2002; Youn et al., 1995). Because of their capability in oxidation of phenols they are receiving increasing interest as potential industrial enzymes in various applications such as pulp bleaching processes (Bourbonnais et al., 1997a, 1997b and 1998; Li et al., 1997), delignification (Leonowicz and Trojanowski, 1975), wood fiber modification (Leonowicz et al., 2001) or remediation of contaminated water (Leonowicz et al., 1997b). They have however a limited effect on lignin degradation due to their oxidative specificity (Leonowicz et al., 1999; Szklarz and Leonowicz, 1986). Moreover, the measurement of pore sizes in wood shows that large molecules such as enzymes (e.g. laccase) does limits the penetration of the undegraded plant cell wall except where the wood cell wall is already partially decayed (Evans et al., 1994; Flournoy et al., 1991). Therefore, in recent years research has been focused on such potential low-molecular mass mediators of internal or external origin, which poses high enough redox potentials $(>900 \mathrm{mV}$ ) to attack lignin and can migrate from the enzymes into tight ligno-

Wood and Paper Science, Chungbuk National University, Cheongju 361-763, Korea

${ }^{2}$ Department of Biochemistry, Maria Curie-Sklodowska University. Lublin Pl 20031, Poland

Molecular Microbiology and Immunology, Keck School of Medicine, University of Southern California, Los Angeles, CA 90089, USA

* Corresponding author (E-mail: ohga@forest.kyushu-u.ac.jp) cellulose complex. Many possible low-molecular mass compounds have been suggested as candidates for a mobile factor to permeate wood cell walls and indicate decay. Some of these, such as veratryl alcohol, oxalate, malate, fumarate, and 3-hydroxyanthranilic acid, are produced as a result of fungal metabolism and their secretion enables the fungi to colonize and degrade the wood cell structure more effectively than other organisms (Eggert et al., 1996; Hofrichter et al., 1998; Lundquist and Kirk, 1978; Potthast et al., 1999; Traquair, 1987). Most of the fungal enzymes are always located within the extracellular polysaccharide sheath surrounding the hyphae i.e. at the cell wall surfaces. The mediators are capable of diffusing from enzymes into the middle of wood cell wall structure and open up the pore size in wood what allow enzymes to penetrate and complete the degradative processes (Evans et al., 1994; Call and Mücke, 1997).

It was also found that delignification of kraft pulp by laccase can be supported by some external (i.e. nonproduced by fungi and absent in pulp) low molecular dyes or other aromatic hydrogen donors as acting mediators such as 2,2'azinobis-(3-ethylbenzenthiazoline-6sulfonic acid - ABTS) (Bourbonnais et al., 1997a; 1997b and 1998) or 1-hydroxybenzotriazole-HBT) (Bourbonnais et al., 1998; Call, 1994; Srebotnik et al., 1988; Srebotnik and Hammel, 2000).

This study was performed to investigate the laccase and mediator co-operation in modelling lignin dimer veratrylglycerol- $\beta$-vanillate ether (VVE) oxidation. Earlier authors stated that constitutive laccase isolated from Cerrena unicolor can cooperate with acetovanillone (AV) and acetosyringone (AS) in degradation of high molecular fraction of lignosulfonates (Leonowicz et al., 2001). The fungus C. unicolor is known as a very 
good producer of cheap constitutive laccase (Gianfreda et al., 1998; Leonowicz et al., 1997a and 1997b). Its cultivation for this reason does not require stimulation by the expensive and toxic for environment compounds such as 2,5-xylidine (Leonowicz et al., 1997b). The present study is to examine capability of $C$. unicolor laccase to oxidize VVE, which is a non-phenolic lignin model compound with external mediators, HBT, AV and AS in order to choose one, most efficient system.

\section{MATERIALS AND METHODS}

\section{Strain and culture conditions}

Cerrena unicolor (Bull. ex Fr.) Murr., Einfarbige Tramete Strain T 143 was kindly provided by the Collection Molitoris, Botanic Institute, University of Regensburg. The fungus was maintained in $2 \%(\mathrm{w} / \mathrm{v})$ malt agar slants. As an inoculum, pieces of agar were grown in the Lindenberg and Holm (1952) medium in non-agitated conical flasks for 7 days at $28^{\circ} \mathrm{C}$. The mycelial mats were subsequently collected and homogenized in a Warring blender.

The fermenter scale cultivation was performed at $28^{\circ} \mathrm{C}$ in a 2.51 Bioflo III (New Brunswick) fermenter containing $2 \mathrm{l}$ of the Lindenberg and Holm (1952) medium. The fermenter was inoculated with crumbled fungal mats ( $10 \%$ total volume), aerated by $1 \mathrm{l}$ air per minute and stirred at $300 \mathrm{rpm}$. Antifoam 289 emulsion (Sigma, St. Louis, USA) was occasionally added to the fermenter cultures.

\section{Reagents}

Veratrylglycerol- $\beta$-vanillate ether (VVE) was synthesized and kindly supplied by Dr. Atsumi Nishida; agar was from Junsei Chemical Co. (Tokyo, Japan); malt and yeast extracts were from DIFCO (Milwaukee, Wi. U.S.A.); syringaldazine (4-hydroxy-3,5-dimethoxybenzaldehydazine), acetovanillone (AV, 4-hydroxy-3-methoxyacetophenone), acetosyringone (AS, 3,5-dimethoxy4-hydroxyacetophenone), HBT (1-hydroxybenzotriazole), alpha-methyl mannoside, and bovine liver catalase were from Aldrich-Chemie (Steinheim, Germany); bovine serum albumin and isovanillic acid (IA) were from Sigma (St. Louis, Mo. U.S.A.); AH-Sepharose-4B, DEAE-Cellulose and Sephadex G-50 'fine' were from Pharmacia (Uppsala, Sweden); syringaldehyde and vanillic acid (VA) were from Fluka A.G. (Buchs, Switzerland).

\section{Determination of protein}

The protein content both in the culture fluids and in laccase preparations was determined according to Bradford (1976). Bovine albumin was used as a standard.

\section{Laccase purification}

For the enzyme purification the method of Leonowicz et al. (1997a) with some our and Gianfreda et al. (1998) modifications was applied as follows. The aerated cultures at the tops of laccase activity were filtered through Miracloth (Calbiochem, Lucerne, Switzerland). Each filtrate was desalted on the Sephadex G-50 column. The enzyme solutions were concentrated to ca. one tenth of the volume at $4{ }^{\circ} \mathrm{C}$ with the Amicon ultrafiltration system equipped with a filter type PTGC (cut off $10 \mathrm{kDa}$ ). Then $50 \mathrm{ml}$ portions of enzyme preparations were applied onto DEAE-Cellulose column $(25 \times 1.5 \mathrm{~cm})$ preequilibrated with $5 \mathrm{mM}$ TRIS/HCL buffer $(\mathrm{pH}$ 6.0) The fractions showing the highest laccase activity were poured onto a column of AH-Sepharose 4B coupled with syringaldehyde column $(25 \times 1.5 \mathrm{~cm})$ equilibrated with $0.01 \mathrm{M}$ citrate-phosphate buffer $\mathrm{pH} 5.0$ prepared according to McIlvaine (1921). The fractions bounded with the carrier were removed by using $0.5 \mathrm{M}\left(\mathrm{NH}_{4}\right)_{2} \mathrm{SO}_{4}$ and stored freeze dried. The enzyme activity both in the culture fluids and in laccase preparations was determined spetrophotometrically at $525 \mathrm{~nm}$ using syringaldazine on a Shimadzu UV-160 spectrophotometer according to Leonowicz and Grzywnowicz (1981). The activity was expressed in nkat per litre. To exclude endogenous peroxide, the $10 \mathrm{~min}$. preincubation (stirring) of the enzyme sample with catalase $(10 \mathrm{mg} / \mathrm{ml})$, was performed. No lignin peroxidase activity was found in the enzyme preparation. (Tien and Kirk, 1988).

\section{Enzyme reaction}

To a flask with $5 \mathrm{ml}$ of $0.1 \mathrm{M}$ Mcllvaine buffer $\mathrm{pH} 5.3$ laccase (300 nkat) was added, VVE $(50 \mu \mathrm{l}$ of $10 \mathrm{mM})$, HBT, AV or AS, each $50 \mu \mathrm{l}$ of $15 \mu \mathrm{M}$. The flasks were rotary shacked $(180 \mathrm{rpm})$ at $28^{\circ} \mathrm{C}$. Control experiments lacked either laccase or mediators in the reaction mixture. The reaction products after alkalization with $1 \mathrm{M}$ $\mathrm{NaOH}$ (to melt the sediment) were extracted twice with one volume of diethyl ether, evaporated under IR lamp and redissolved in 50\% ethanol.

\section{Thin-layer chromatography}

Extracts were evaporated to small volumes and analyzed by TLC on silica-gel plates (DC-Alurolle Kieselgel 60 F 254 from Merck) according to Leonowicz et al. (1984) using the solvent system benzene : methanol : propionic acid (88:8:4). The phenolics were visualized with diazosulfamide reagent according to the procedure described by Leonowicz et al. (1968).

\section{Capillary electrophoresis}

Micellar electrokinetic chromatography (MEKC) analyses were performed on Spectra 100 Thermo Separation Products (San Jose, USA). The separations were carried out using fused silica capillary with a total length of $69 \mathrm{~cm}$ ( $44 \mathrm{~cm}$ to detection window) and an inner diameter of $50 \mu \mathrm{m}$. Applied voltage was $29 \mathrm{kV}$ and the capillary temperature was maintained at $25^{\circ} \mathrm{C}$. Injection was done in the hydrodynamic mode for $0.5 \mathrm{~s}$. Detection was performed by measuring absorbance at $210 \mathrm{~nm}$. Buffer solution used was $100 \mathrm{mM}$ boric acid with $100 \mathrm{mM}$ SDS at pH 8.8 (adjusted with $\mathrm{NaOH}$ ). All samples, buffer solutions, and conditionings before use were filtered through $0.22 \mu \mathrm{m}$ filters. 


\section{RESULTS AND DISCUSSION}

\section{Laccase isolation and purification}

The C. unicolor extracellular laccase was isolated and purified from aerated fermenter culture. The final enzyme preparation was purified more than 32-fold (Table 1). No lignin peroxidase activity was found in the enzyme preparation (Tien and Kirk 1988). It seems that our laccase using 4 steps of purification was sufficiently purified to carry out the investigations whose are presented in this paper.

\section{Transformation of substrate (VVE, veratrylglycol- $\beta$-vanillate ether) by laccase and laccase/mediator couples}

Transformations of VVE by laccase alone and laccase/mediator systems (Mediators chemical structures Fig. 1) are different. The results shown in Fig. 2 confirm much more efficient reaction with laccase/mediator systems than with laccase alone. The transformation efficiency (mediating activity) of laccase/AV and laccase/AS systems (Fig. 2) was comparable to laccase/HBT system and even better in the case of laccase/AS than laccase/ HBT. This result shows that AV and AS can work as laccase mediators.

\section{Mediation efficiency}

Studying the VVE depolymerization process further we examined the products of mediating activity. When laccase and the mediators were incubated with VVE depolymerization occurred. The resulted vanillic acid (VA) and isovanillic acid (IA) were detected both chromatically (Table 2) and by capillary electrophoresis (Figs. 3, 4 and 5). The control map (without laccase) of capillary electrophoresis of substrate, mediators and products is presented in Fig. 3.

As shown in Table 2 and illustrated in Figs. 4, 5 and 6 with reference to control map (Fig. 3) laccase and laccase/mediator systems partly transform the substrate VVE into IA and VA. No significant difference was observed between $6 \mathrm{~h}$ and $12 \mathrm{~h}$ incubation. At the moment although we do not have an reliable mechanistic

Table 1. Isolation and purification of C. unicolor laccase

\begin{tabular}{lcccc}
\hline \multicolumn{1}{c}{ Purification step } & $\begin{array}{c}\text { Total activity } \\
\text { (nkat/1) }\end{array}$ & $\begin{array}{c}\text { Specific activity } \\
\text { (nkat/mg) }\end{array}$ & $\begin{array}{c}\text { Yield } \\
\text { (\%) }\end{array}$ & $\begin{array}{c}\text { Purification } \\
\text { (fold) }\end{array}$ \\
\hline Culture filterates & 87458 & 436.83 & 100.00 & 1.00 \\
Sephadex G-50 & 80147 & 520.44 & 91.64 & 1.19 \\
Ultrafiltration & 69785 & 2791.40 & 79.79 & 6.39 \\
DEAE-Cellulose & 45874 & 11468.50 & 52.45 & 26.25 \\
Syringyl-AH-Sepharose 4B & 29874 & 14225.71 & 34.16 & 32.57 \\
\hline
\end{tabular}
layer chromatography

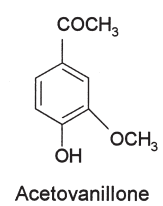

(AV)

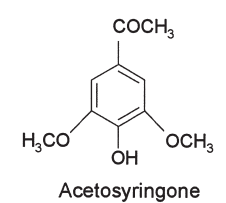

(AS)



1-hydroxybenzotriazole (HBT)

Fig. 1. Chemical structure of used mediators.

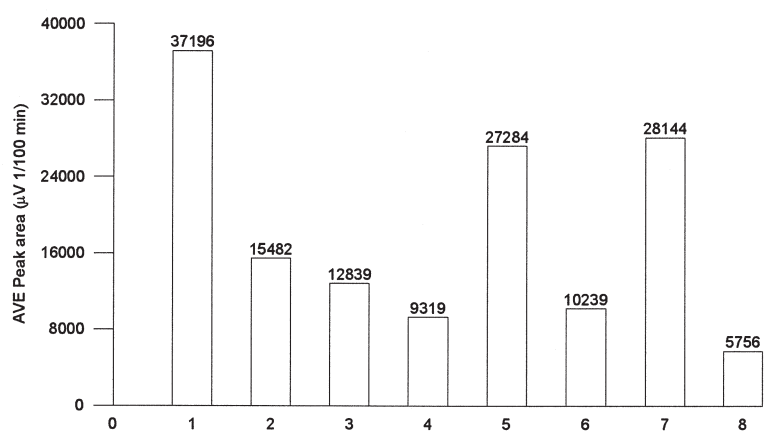

Fig. 2. VVE (veratrylglycol- $\beta$-vanillate ether) transformations by laccase, and laccase/mediator systems. 1=laccase+VVE after $6 \mathrm{~h}$ incubation; $2=12 \mathrm{~h} ; 3=$ laccase/HBT+VVE after 6 h; $4=12$ h; 5=laccase/AV (acetovanillone)+VVE, 6h; 6=12 h; $7=$ laccase/AS (acetosyringone) +VVE, $6 \mathrm{~h} ; 8=12 \mathrm{~h}$.

\begin{tabular}{ccc}
\hline Aromatic acid & $\begin{array}{r}\text { Rf of commercial } \\
\text { compounds }\end{array}$ & $\begin{array}{c}\text { Rf of reaction } \\
\text { products }\end{array}$ \\
\hline Isovanillic acid (IA) & 0.5912 & 0.5898 \\
Vanillic acid (VA) & 0.6759 & 0.6777 \\
\hline
\end{tabular}

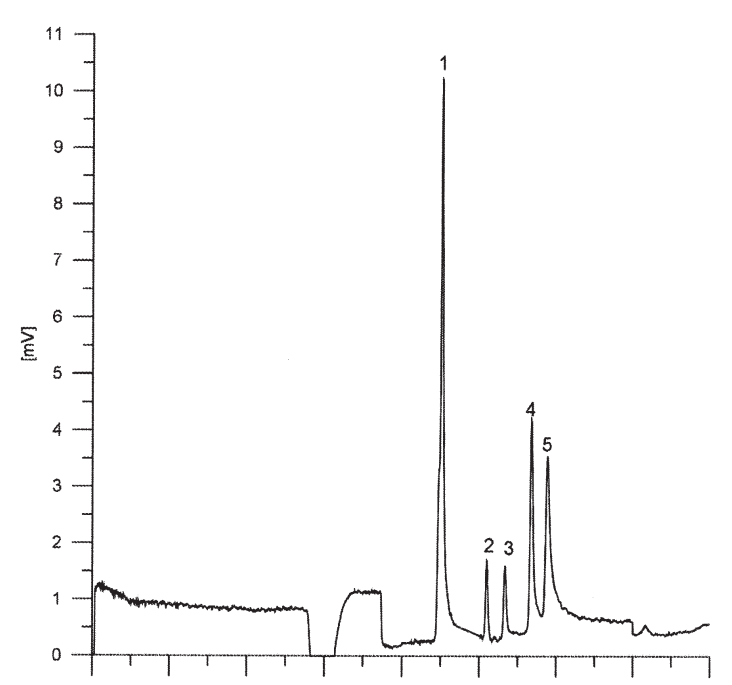

Fig. 3. Capillary electrophoresis of substrate, mediators and products (control map): 1=VVE; 2=IA (isovanillic acid); $3=\mathrm{VA}$ (vanillic acid); 4=AV; 5=AS. All abbreviations refer to Fig. 2. 
explanation for this result, tentative VVE degradation scheme could be proposed as shown in Fig. 7 based on the capillary electrophoresis results by the laccase/mediator systems. A similar observation has previously been reported by Li et al. (1997) studying the degradation of a lignin $\beta-0-4$ dimer, 1-(3,4-dimethoxy)propan-1,3diol. The presented results in this report show that some laccase is able for transformation lignin model dimer and that AV and AS stimulated the process. As can be seen in Fig. 2, AS was even more efficient than HBT. As well AV as AS (contrary to already known mediators, like HBT or ABTS), are produced in the processes of wood transformation, have less complicated formulae and are cheaper than ABTS or HBT. The sources
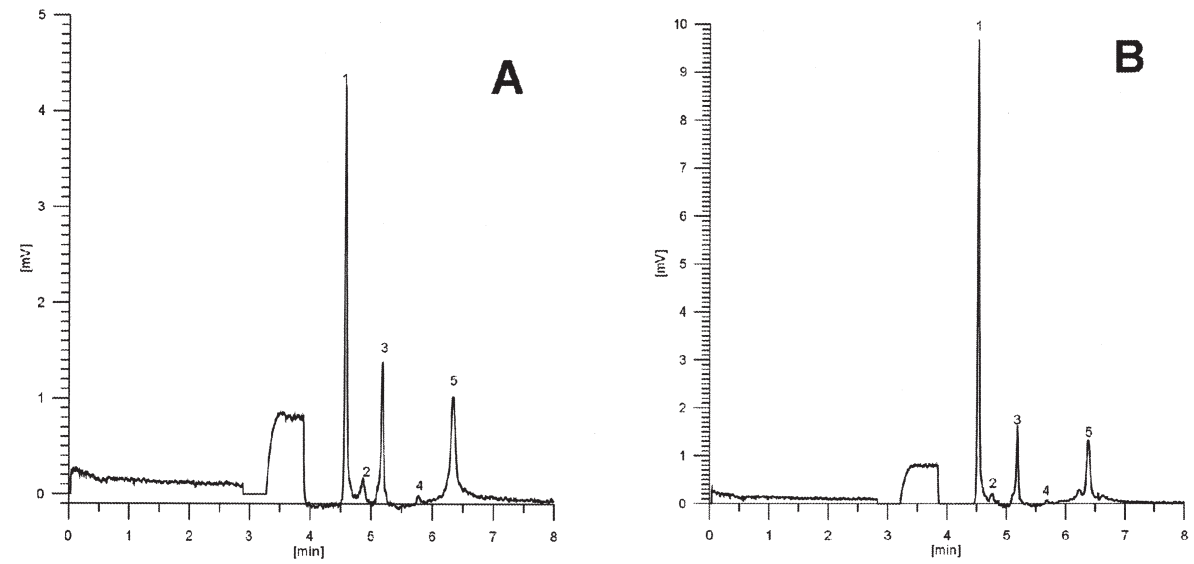

Fig. 4. Capillary electrophoresis of laccase reaction on VVE: A-after $6 \mathrm{~h}$ incubation; B-after $12 \mathrm{~h}$ : 1=VVE; $2=$ unknown; 3=IA; 4=VA; 5=unknown. All abbreviations refer to Fig. 2.
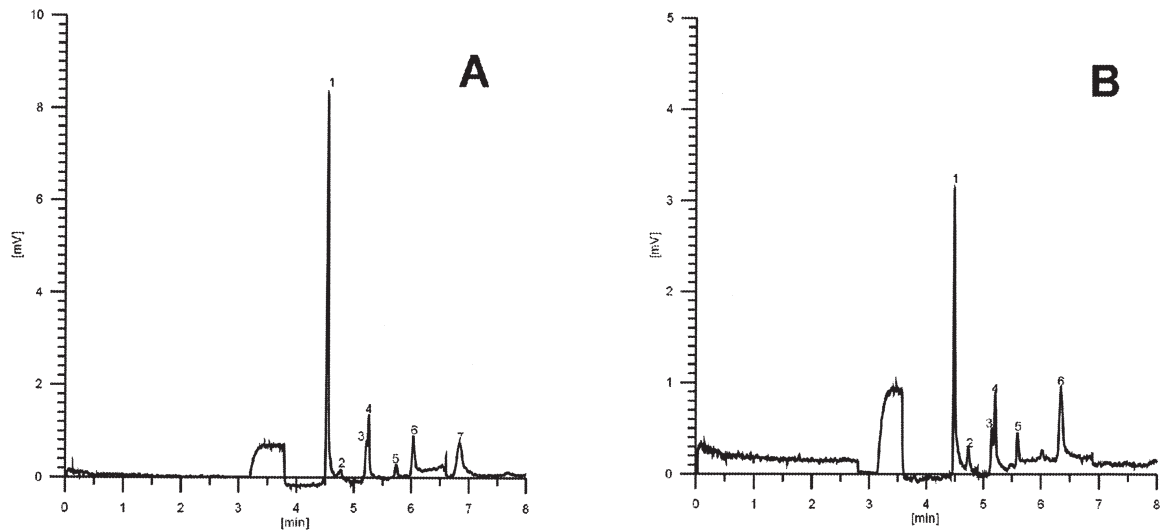

Fig. 5. Capillary electrophoresis of laccase and laccase/acetovanillone reaction on VVE: A-after $6 \mathrm{~h}$ incubation; B-after $12 \mathrm{~h}$ : 1=VVE; 2=unknown; 3=IA; 4=VA; 5=AV; 6 and $7=$ unknown. All abbreviations refer to Fig. 2.
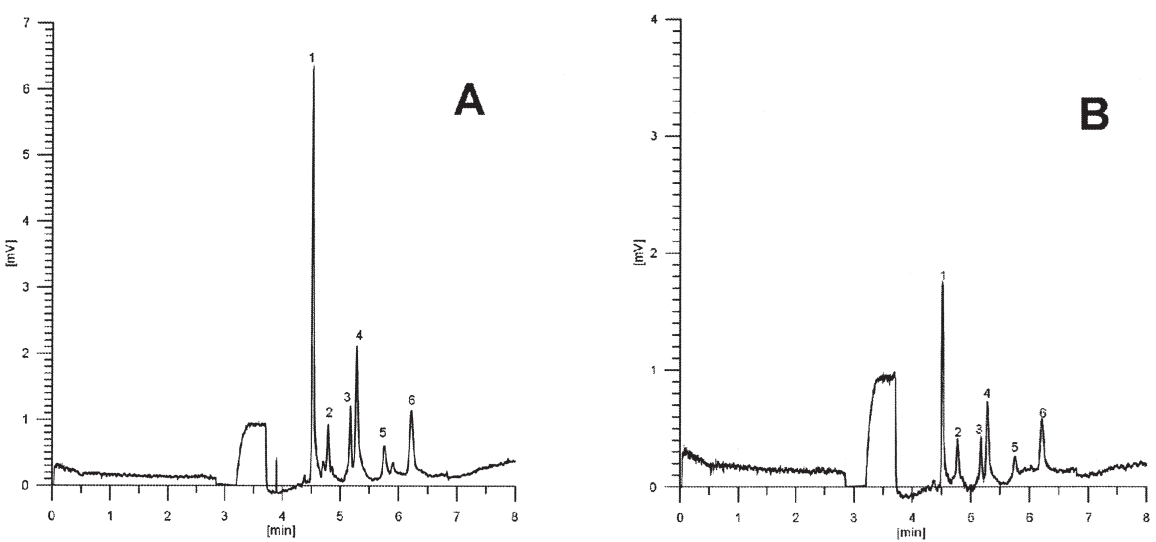

Fig. 6. Capillary electrophoresis of laccase and laccase/acetosyringone reaction on VVE: A-after $6 \mathrm{~h}$ incubation; B-after $12 \mathrm{~h}$ : $1=\mathrm{VVE} ; 2=$ unknown; $3=\mathrm{IA} ; 4=\mathrm{VA} ; 5=\mathrm{AS} ; 6=$ unknown. All abbreviations refer to Fig. 2. 


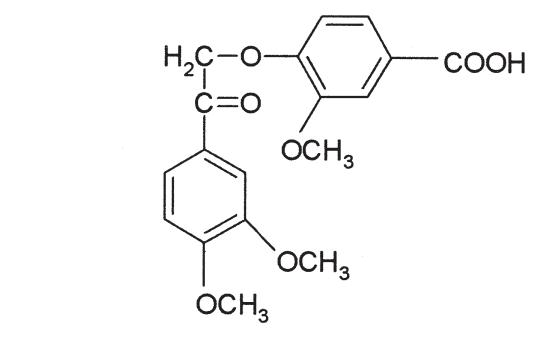

veratrylglycerol- $\beta$-vanillate ether (VVE)



isovanillic acid (IA)

Fig. 7. Possible route of VVE transformation by laccase/mediator systems.

of lignocellulose that occur in various forms in nature (mainly as wood) are so vast that they can only be compared to those of water (Leonowicz et al., 2001). The results presented in this report show that laccase with using of some compounds as mediators is able for degradation of dimer being a model compound of lignin, which is the most undegradable constituent of lignocellulose complex. It may be one more (biotechnological) system for the bleaching of kraft pulps, in combination with oxygen delignification techniques.

\section{ACKNOWLEDGEMENTS}

Parts of this work were carried out with the supports of Korean Research Foundation (KRF 2001-042G00015), the European Community (Contract ICA2CT-2000-10050) and the Polish Committee for Scientific Investigations 139/E-339/SPUB-M-5PR-UE/DZ 280/200, BW/BiNoZ/4 and BS/BiNoZ/4.

\section{REFERENCES}

Bourbonnais, R., D. Leech and M. G. Paice 1998 Electrochemical analysis of the interactions of laccase mediators with lignin model compounds. Biochem. Biophys. Acta, 1379: 381-390

Bourbonnais, R., M. G. Paice, I. D. Reid and B. Freiermuth 1997a Reactivity and mechanism of laccase mediators for pulp delignification. TAPPI Proc. Biol. Sci. Symp. TAPPI Press. 1997, 335-338

Bourbonnais, R., M. G. Paice, I. D. Reid and B. Freiermuth 1997b Reactivities of various mediators and laccases with kraft pulp and lignin model compounds. Appl. Environ. Microbiol., 63: 4627-4632

Bradford, M. M. 1976 A rapid and sensitive method for the quantitation of microgram quantities of protein utilizing the principle of protein-dye binding. Anal. Biochem., 72: 248254

Call, H. P. 1994 Process for modifing, breaking down or or bleaching lignin, materials containing lignin or like substances. PCT World Pat. Appl. WO94/29510

Call, H. P. and I. Mücke 1997 History, overview and application of mediated lignolytic systems, especially laccase-mediator-systems (Lignozym-process). J. Biotechnol., 53: 163202

Eggert, C., U. Temp, J. F. Dean and K. E. Eriksson 1996 A fungal metabolite mediates degradation of non-phenolic lignin structures and synthetic lignin by laccase. FEBS Lett., 391:
$144-148$

Evans, C. S., M. V. Dulton, F. Guillen and R. G. Veness 1994 Enzymes and small molecular mass agents involved with lignocellulose degradation. FEMS Microbiol. Rev., 13: 235240

Fluornoy, D. S., T. K. Kirk and T. L. Highley 1991 Wood decay by brown-rot fungi: changes in pore structure and cell wall volume. Holzforschung, 45: 383-388

Gianfreda, L., F. Sannino, M. T. Lilazzola and A. Leonowicz 1998 Catalytic behavior and detoxyfying ability of laccase from the fungal strain Cerrena unicolor. J. Mol. Cat., 4: 13-23

Hofrichter, M., D. Ziegenhagen, T. Vares, M. Friedrich, M. G. Jager, W. Frische and A. Hatakka 1998 Oxidative decomposition of malonic acid as basis for the action of manganese peroxidase in the absence of hydrogen peroxide. FEBS Lett., 434 $362-366$

Leonowicz, A. and J.Trojanowski 1975 Induction of a new laccase form in the fungus Pleurotus ostreatus by ferulic acid. Microbios., 13: 167-174

Leonowicz, A. and K. Grzywnowicz 1981 Quantitative estimation of laccase forms in some white-rot fungi using syringaldazine as a substrate. Enz. Microb. Technol., 3: 55-58

Leonowicz, A., B. Wojtowicz and J. Trojanowski. 1968 Model experiments on the humification of rye rots. I. Phenolic products in the humification process. Polish J. Soil Sci., 1: $120-136$

Leonowicz, A., J. Rogalski, M. Jaszek, J. Luterek, M. WojtasWasilewska, E. Malarczyk, G. Ginalska, M. Fink-Boots and N. -S. Cho 1999 Cooperation of fungal laccase ang glucose 1-oxidase in transformation of Bjorkman lignin and some phenolic compounds. Holzforschung, 53: 376-380

Leonowicz A., L. Gianfreda, J. Rogalski, M. Jaszek, J. Luterek, M. Wojtas- Wasilewska, E. Malarczyk, A. Dawidowicz, M. FinkBoots, G. Ginalska and N. S. Cho 1997a Purification of extracellular Cerrena unicolor laccase by means of affinity chromatography, J. KTAPPI, 29: 7-17

Leonowicz, A., L. Gianfreda, J. Rogalski, M. Jaszek, J. Luterek, M. Wojtas-Wasilewska, E. Malarczyk, A. Dawidowicz, M. FinkBoots, G. Ginalska, M. Staszczak and N. S. Cho. 1997b Appearance of lacase in wood-rotting fungi and its inducibility. J. Kor. Wood Sci. Technol. 25: 29-36

Leonowicz, A., N. S. Cho, J. Luterek, A. Wilkolazka, M. WojtasWasilewska, A. Matuszewska, M. Hofrichter, D. Wesenberg and J. Rogalski 2001 Fungal laccase: properties and activity on lignin. J. Basic. Microbiol. 41: 185-227

Leonowicz. A., R. U. Edgehill and J. M. Bollag 1984 The effect of $\mathrm{pH}$ on the transformation of syringic and vanillic acids by the laccase of Rhizoctonia praticola and Trametes versicolor. Arch. Microbiol. 137: 89-96

Li, K., H. Bermek and K. E. Eriksson 1997 A new technique for screening of laccase mediators., Biological Sciences Symposium 1997, 349-353 
Lindenberg, G. and G. Holm 1952 Occurance of tyrosinase and laccase in fruit bodies and mycelia of some Hymenomycetes. Physiol. Plant., 5: 100-114

Lundquist, K. and T. K. Kirk 1978 De novo synthesis and decomposition of veratryl alcohol by a lignin-degrading basidiomycete. Phytochem., 17: 1676

Mayer, A. M. and R. C. Staples 2002 Laccase: new functions for an old enzyme. Phytochem., 60: 551-565

McIlvaine, T. C. 1921 A buffer solution for colorimetric comparison. J. Biol. Chem., 49: 183-186

Potthast, A., T. Rosenau, P. Kosma and K. Fisher 1999 Chemistry and kinetics of the laccase-mediator system. In: Proceeding of the 10th International Symposium on Wood and Pulping Chemistry. Yokohama, Japan 1999: vol 1. pp. $596-601$

Srebotnik, E. and K. E. Hammel 2000 Degradation of non-phenolic lignin by the laccase/1-hydroxybenzotriazole system. J. Biotechnol., 81: 178-188

Srebotnik, E., K. A. Jensen and K. E. Hammel 1988 Cleavage of nonphenolic lignin structures by laccase in the presence of 1-hydroxybenzotriazole. In: Proceedings of the 7th International Conference on Biotechnology in the Pulp and Paper Industry. Vancouver, Canada 1988; pp. B195-B197

Szklarz, G. and A. Leonowicz 1986 Cooperation between fungal laccase and glucose oxidase in the degradation of lignin derivatives. Phytochem., 25: 2537-2539

Tien, M. and T. K. Kirk 1988 Lignin peroxidase of Phanerochaete chrysosporium. In: Methods in Enzymology Vol. 161B. Eds. D. A. Wood, S. T. Kellogg. Academic Press, San Diego, CA. pp. 238-249

Traquair, J. A 1987 Oxalic acid and calcium oxalate produced by Leucostoloma cincta and L. personii in cultures and in peach bark tissue. Can. J. Bot., 65: 1952-1956

Youn, H. D., K. J. Kim, J. S. Maeng, Y. H. Han, G. Jeon, S. O. Kang and Y. C. Hah 1995 Single electron trasfer by an extracellular laccase from white-rot fungus Pleurotus ostreatus, Microbiology, 141: 393-398 